\title{
IDENTIFIKASI BIAYA TRANSAKSI DI PASAR INPUT USAHA PERIKANAN TANGKAP (STUDI KASUS DI PANTAI SENDANGBIRU, MALANG)
}

\section{Transaction Cost in Input Market of Commercial Fishing Business (Case Study in the Sendangbiru Beach, Malang)}

\author{
${ }^{*}$ Anthon Efani ${ }^{1}$, Asfi Manzilati ${ }^{2}$, dan Yenny Kornitasari ${ }^{2}$ \\ ${ }^{1}$ Fakultas Perikanan dan Ilmu Kelautan, Universitas Brawijaya \\ JI. Veteran No.16, Ketawanggede, Kec. Lowokwaru, Kota Malang, Jawa Timur 65145, Indonesia \\ ${ }^{2}$ Fakultas Ekonomi dan Bisnis, Universitas Brawijaya \\ Jalan MT. Haryono 165, Malang 65145; Phone. (0341) 551396, 555 000, Indonesia \\ Diterima tanggal: 5 Desember 2018 Diterima setelah perbaikan: 20 Juli 2019 \\ Disetujui terbit: 10 Desember 2019
}

\begin{abstract}
ABSTRAK
Ketersediaan input produksi serta kedekatan akses nelayan pada pasar input merupakan hal penting dalam kegiatan usaha. Berdasarkan pada hal tersebut penelitian ini bertujuan untuk mengidentifikasi terbentuknya biaya transaksi pada kegiatan usaha perikanan tangkap di Sendangbiru dan menganalisis biaya transaksi yang terdapat di pasar input usaha perikanan tangkap. Metode penelitian yang digunakan adalah kualitatif. Berdasarkan hasil penelitian, terbentuknya biaya transaksi pada usaha perikanan muncul ketika kontrak bisnis antara nelayan dan pengambek telah disepakati. Meskipun kontrak bersifat informal, namun kontrak tersebut merupakan kelembagaan yang eksis dan mengatur seluruh kegiatan usaha perikanan tangkap di Sendangbiru. Biaya transaksi di pasar input usaha perikanan tangkap di Pantai Sendangbiru terdiri dari biaya komunikasi, selisih harga pada barang - barang input produksi yang disediakan oleh pengambek, dan biaya jasa pengiriman perbekalan oleh kuli bongkar ke kapal nelayan.
\end{abstract}

Kata kunci: biaya transaksi; usaha perikanan tangkap

\begin{abstract}
The availability of input production and accessible input market for fishers are essential parts in supporting business activity. Based on those matters, the aims of this research are to identify the transaction cost in commercial fishing business in Sendangbiru and to analyze transaction cost in input market of commercial fishing business. The research used qualitative method. The result of this research is transaction cost emerges when business deal between fishermen and pengambek has been approved. Nevertheless, the informal transaction is an essential part which exists and regulates the entire commercial fishing business activity in Sendangbiru. Transaction cost in input market of commercial fishing business comprise of communication cost, price difference of production input goods provided by pengambek, and service cost such delivering supplies by porter to fishers ship.
\end{abstract}

Keywords: capacity; transcation cost; commercial fishing business

\section{PENDAHULUAN}

Potensi sumber daya ikan tuna di Pantai Sendangbiru menjadikan Kabupaten Malang sebagai penghasil ikan tuna terbesar di Jawa Timur (Jaya, Wiryawan \& Simbolon, 2017).Pencapaian ini diharapkan dapat menjadikan Sendangbiru sebagai sentra perdagangan ikan tuna. Hal ini sejalan dengan laporan UPT P2SKP Pondok dadap yang menunjukkan produksi tahunan ikan tuna di Sendangbiru pada tahun 2017 sebesar 75.516.146 $\mathrm{kg}$. Hasil tangkapan tuna yang didaratkan di pelabuhan mencapai ratusan ton per hari. Kondisi ini tentu saja memicu peningkatan aktivitas ekonomi masyarakat pesisir dan nelayan yang berbanding lurus dengan kesejahteraan mereka.

Melimpahnya sumber daya alam Sendangbiru telah menjadi daya tarik bagi masyarakat dari daerah lain. Terbukti dari keberagaman penduduk Sendangbiru yang terdiri dari penduduk asli dengan mayoritas suku jawa serta penduduk pendatang yang berasal dari Sulawesi Selatan (Bugis), Kalimantan dan Madura. 
Mereka melakukan migrasi atau berpindah tempat karena semata untuk mencari ikan sebanyak-banyaknya dan berharap mendapat kan penghasilan yang lebih (Ismadi, 2010). Lebih dari itu, pada tahun 2017 jumlah nelayan di Sendangbiru sebanyak 380 unit kapal sekoci. Sementara untuk jenis kapal speedboat sebanyak 260 unit, 52 unit kapal jenis seleret dan 92 kapal dayung (P2SKP Pondokdadap, 2017).

Jumlah kapal di Sendangbiru yang mencapai lebih dari 500 unit dengan beberapa spesifikasi tidak hanya dapat menghasilkan ikan yang melimpah. Membutuhkan sumber daya modal yang tidak sedikit untuk mencukupi biaya operasional nelayan untuk melaut. Cahyono \& Nadjib (2014) mengatakan bahwa pada usaha penangkapan ikan merupakan usaha yang padat modal, sehingga dibutuhkan dana relatif besar untuk pengadaan perahu, mesin perahu, jaring, dan biaya operasional penangkapan. Ketersediaan input produksi bagi nelayan menjadi penting terutama saat musim ikan, karena nelayan akan berlomba lomba untuk pergi melaut agar mendapatkan ikan. Keuntungan maksimum akan tercapai apabila semua faktor produksi (alam, modal, tenaga kerja dan skill) telah dialokasikan penggunaanya secara optimal dan efisien, baik efisiensi secara teknik, harga maupun ekonomi. Hal tersebut berarti nelayan harus optimal dalam menggunakan input produksi agar tercapainya suatu produktivitas yang tinggi, sekaligus melakukan efisiensi biaya (Suharto, 2012).

Selain ketersediaan modal, ketersediaan input produksi serta kedekatan akses nelayan pada pasar input merupakan hal penting dalam kegiatan usaha. Karena salah satu hal utama yang mempengaruhi usaha penangkapan adalah aktifitas penangkapan yang salah satunya adalah pemenuhan perbekalan selama melaut Efani (2010). Maka untuk meningkatkan pendapatan dan efisiensi maka akses pelaku usaha ke pasar input harus dekat dan mudah (Zakaria, 2009 dalam Siswoyo, Setyono \& Fuah, 2013). Dalam praktiknya terdapat kelembagaan yang mengatur mekanisme pasar input sebuah kegiatan usaha. Misalnya akses untuk masuk dalam mekanisme pasar serta kemudahan dalam mendapatkan barang yang dibutuhkan. Manzilati, Efani \& Kornitasari (2018) menjelaskan tentang kelembagaan kontrak bisnis pesisir yang eksis di Sendangbiru bahwa kontrak bisnis tersebut mengatur seluruh aktivitas bisnis mulai dari input hingga output produksi.
Sejalan dengan Yustika (2012) bahwa biaya transaksi merupakan pengeluaran diluar biaya produksi yang sekaligus merupakan indikator efisiensi ekonomi. Jika biaya produksi menjadi tinggi, maka harga barang semakin naik dan mengurangi pendapatan nelayan (Halim, 2013). Sebagaimana dijelaskan diatas bahwa terdapat kelembagaan yang mengatur hampir keseluruhan kegiatan usaha di Sendangbiru termasuk dalam pemenuhan input produksi, dan Informasi mengenai pengaruh input produksi sangat diperlukan agar usaha penangkapan berjalan optimal dengan penggunaan input produksi yang efektif dan efisien agar dapat meningkatkan pendapatan nelayan (Alhuda, Anna \& Rustikawati, 2016). Dengan demikian, penelitian ini penting dilakukan untuk menguraikan sistem pasar input di Sendangbiru serta mengidentifikasi biaya transaksi yang harus dikeluarkan oleh pelaku usaha penangkapan. Karena biaya transaksi yang muncul pada pasar input (input produksi) mengakibatkan harga barang menjadi lebih mahal, sehingga dapat menurunkan kapasitas nelayan untuk melakukan kegiatan produksi.

\section{METODOLOGI}

\section{Lokasi dan Waktu Penelitian}

Lokasi penelitian di Pantai Sendangbiru, Desa Tambakrejo, Kecamatan Sumbermanjing Wetan, Kabupaten Malang. Penelitian ini dilaksanakan mulai bulan Agustus - November 2018.

\section{Jenis dan Metode Pengambilan Data}

Data yang digunakan dalam penelitian ini adalah data sekunder dan primer. Teknik pengumpulan data dilakukan dengan metode wawancara, observasi dan dokumentasi. Metode wawancara dalam penelitian ini adalah wawancara tidak terstruktur. Metode ini digunakan untuk menggali informasi tentang biaya transaksi dan proses terbentuknya pada usaha perikanan tangkap. Obsevasi merupakan suatu metode pengumpulan data dan informasi dengan jalan mengadakan pengamatan atas peristiwa dan gejala sosial dengan pancaindera. Observasi ini sekaligus berfungsi untuk memastikan informasi yang diperoleh (triangulasi atas wawancara dan informasi lainnya). Black \& Champion (2001) menjelaskan bahwa observasi adalah kegiatan mengamati dan mendengar perilaku seseorang selama beberapa waktu, seta mencatat penemuan yang memungkinkan untuk digunakan dalam 
tingkat penafsiran. Kemudian kedua metode tersebut diperkuat dengan dokumentasi. Dokumentasi sekaligus menjadi bukti yang digunakan untuk menguji, menafsirkan, bahkan meramalkan suatu data.

\section{Metode Analisis}

Penelitian ini merupakan penelitian kualitatif sehingga teknik analisis data dilakukan sejak sebelum melakukan pencarian data di lapang, saat berada di lapang dan setelah selesai dari lapang (Sugiyono, 2014). Penelitian ini berusaha menekankan pada proses yang lebih mendalam tentang biaya transaksi dan proses terbentuknya pada pasar input usaha perikanan tangkap di Sendangbiru. Hal ini sejalan dengan Moleong (2006) yang menjelaskan bahwa penelitian kualitatif bermaksud memahami fenomena tentang apa yang dialami oleh subjek penelitian, misalnya: perilaku, persepsi, motivasi, tindakan, dan lain-lain secara holistik, dan dengan cara deskripsi dalam bentuk kata-kata dan bahasa, pada suatu konteks khusus yang alamiah dan dengan memanfaatkan berbagai metode alamiah. Lebih lanjut untuk mengidentifikasi dan menganalisis biaya transaksi di pasar input digunakan teknik analisis interaktif. Teknik analisis data interaktif dimulai dari pengumpulan data, kemudian melakukan reduksi, selanjutnya melakukan verifikasi, penyajian data dan ditarik kesimpulan (Miles \& Huberman, 2014).

\section{HASIL DAN PEMBAHASAN}

\section{Karakteristik Usaha Perikanan Tangkap di Pantai Sendangbiru}

Kegiatan usaha perikanan tangkap di Sendangbiru merupakan sumber mata pencaharian hampir seluruh penduduknya. Jenis kapal yang digunakan oleh nelayan Sendangbiru terdiri dari 3 jenis yaitu, kapal motor, kapal motor tempel, dan perahu tanpa motor. Alat tangkap yang digunakan terdiri dari beberapa jenis tergantung dari kapal yang digunakan. Alat tangkap purse seine dan pancing tonda dioperasikan menggunakan kapal motor dengan lama fishing trip sekitar satu sampai dua minggu. Hasil tangkapan yang didapatkan dari kapal motor harus didaratkan ke Tempat Pelelangan Ikan (TPI) untuk dilakukan pelelangan sebelum dipasarkan.

Alat tangkap pancing jukung dioperasikan menggunakan perahu motor tempel dengan hasil tangkapan ikan lemadang dan ikan tongkol.
Perahu motor tempel memiliki ukuran yang lebih kecil dibandingkan dengan kapal motor. Lama perjalanan melaut kapal motor tempel pun lebih singkat sekitar setengah hari. Perbekalan yang dibutuhkan oleh nelayan dengan alat tangkap jukung tidak terlalu banyak, selain kebutuhan BBM biasanya mereka membawa bekal makanan dari rumah.

Alat tangkap lain yang juga digunakan oleh nelayan Sendangbiru adalah Kunting. Kunting dioperasikan pada daerah perairan dangkal menggunakan kapal kecil yang dikemudikan oleh satu orang. Ikan yang ditangkap menggunakan alat tangkap ini seperti cumi, gurita dan udang. Jika hasil tangkapan dari kapal motor dan perahu motor tempel harus melalui pelelangan sebelum ikan bisa dijual, hasil tangkapan perahu kunting bisa langsung dijual ke pedagang yang ada di pasar ikan tanpa melalui pelelangan. Saat ini di Sendangbiru tidak banyak lagi nelayan yang menggunakan perahu kunting untuk mencari ikan. Kebanyakan kapal kecil milik nelayan beralih menjadi kapal angkutan yang digunakan untuk mengantarkan wisatawan yang ingin menyeberang ke Pulau Sempu.

\section{Kondisi Sosial dan Ekonomi Masyarakat Sendangbiru}

Pantai Sendangbiru merupakan salah satu dusun yang secara administratif terletak di Desa Tambakrejo, Kecamatan Sumbermanjing Wetan, Kabupaten Malang. Jumlah penduduk Desa Tambakrejo berdasarkan data desa tahun 2017 adalah 8.284 jiwa. Dari angka tersebut sebagian besar berjenis kelamin perempuan yaitu 4.706 jiwa, dan sisanya 3.578 jiwa berjenis kelamin laki - laki.

Tingkat pendidikan masih didominasi oleh lulusan SD yaitu 1.636 jiwa dengan jenis kelamin laki - laki, sedangkan 1.542 jiwa berjenis kelamin perempuan. Berikut adalah data tingkat pendidikan penduduk Desa Tambakrejo yang ditampilkan pada Tabel 1.

Data pada Tabel 1 menunjukkan bahwa tingkat pendidikan masyarakat Desa Tambakrejo tergolong rendah. Meskipun demikian, berdasarkan indeks desa membangun Desa Tambakrejo masuk pada kategori maju dengan rata - rata nilai Indek Desa Membangun sebesar 0,75403671. Penilaian Indeks Desa Membangun berdasarkan indikator ketahanan ekonomi, ketahanan sosial dan ketahanan ekologi yang dibuat oleh Kementerian Desa, Pembangunan Daerah Tertinggal dan Transmigrasi. 
Tabel 1. Tingkat Pendidikan Penduduk Desa Tambakrejo, Kabupten Malang, 2007. Table 1. Citizen Education Degree of Tambakrejo Village, Malang District, 2007

\begin{tabular}{llcc}
\hline No & Tingkatan Pendidikan/Education Level & Laki - Laki/Male & Perempuan/Female \\
\hline 1 & Tamat SD sederajat/Elementary & 1,636 & 1,542 \\
2 & Tamat SMP /Sederajat/Junior High School & 226 & 212 \\
4 & Tamat SMA / sederajat/Senior High School & 98 & 72 \\
5 & Tamat D2/Diploma 2 & - & 5 \\
6 & Tamat S1/Bachelor Degree & 8 & 7 \\
\hline & Jumlah/Total & $\mathbf{1 , 9 6 8}$ & $\mathbf{1 , 8 3 8}$ \\
\hline
\end{tabular}

Sumber: Data Desa Tambakrejo, 2017/ Source: Data of Tambakrejo Village, 2017.

Jika dilihat dari jenis pekerjaan penduduk Desa Tambakrejo, mayoritas berprofesi sebagai nelayan yaitu 2.169 jiwa. Sementara itu, sejumlah 4.309 jiwa penduduk Desa Tambakrejo tidak bekerja. Nilai tersebut terdiri dari penduduk pada usia sekolah yang belum mendapat pekerjaan serta usia lansia yang memang sudah tidak mampu bekerja. Apabila jumlah tersebut dikurangi dengan usia pendidikan yg belum mendapat pekerjaan sebesar 3.927 jiwa, maka jumlah penduduk Desa Tambakrejo yang tidak bekerja adalah sebesar 382 jiwa atau sekitar 4,61\% dapat dilihat pada Tabel 2.

Penyedia Input Produksi Usaha Perikanan Tangkap di Sendangbiru

Banyaknya jumlah penduduk Desa Tambakejo yang menjadi nelayan tidak hanya memberikan keuntungan bagi rumah tangga nelayan itu sendiri. Untuk menunjang kegiatan usaha perikanan di Sendangbiru harus didukung dengan kemudahan akses pada sarana produksi. Kebutuhan operasional seperti BBM, perlengkapan penangkapan dan perbekalan harus dipenuhi untuk kelancaran kegiatan usaha. Jaringan penyedia sarana produksi usaha penangkapan di Sendangbiru terdiri dari lembaga maupun perseorangan. Jarak antara titik pemberangkatan kapal dengan penyedia sarana produksi sangat dekat dan akses yang sangat mudah.

Kebutuhan sehari - hari seperti BBM dan logistik saat melaut dapat diperoleh dengan mudah oleh nelayan karena lokasi yang mudah dijangkau. Nelayan bekerjasama dengan kuli bongkar untuk pengiriman barang - barang tersebut. Berikut adalah pihak - pihak yang berperan dalam penyediaan sarana produksi pada usaha perikanan di Sendangbiru.

\section{KUD Minajaya}

KUD Minajaya adalah satu - satunya koperasi yang ada di Sendangbiru sehingga keberadaanya sangat penting bagi kegiatan perekonomian masyarakat. Dalam kegiatan usaha perikanan KUD Minajaya merupakan lembaga yang menyediakan sarana produksi seperti air, BBM dan es batu.

Tabel 2. Kesempatan Kerja Penduduk Desa Tambakrejo, Kabupaten Malang Tahun 2017.

Table 2. Citizen Job Opprtunities of Tambakrejo Village, Malang District 2017.

\begin{tabular}{clrr}
\hline No & \multicolumn{1}{c}{$\begin{array}{c}\text { Jenis Pekerjaan/ } \\
\text { Type of work }\end{array}$} & $\begin{array}{c}\text { Jumlah (Jiwa)/ } \\
\text { Amount (Person) }\end{array}$ & $\begin{array}{c}\text { Prosentase (\%)/ } \\
\text { Percentage (\%) }\end{array}$ \\
\hline 1 & Petani/Farmer & 1,111 & 13.41 \\
2 & Nelayan/Fishers & 2,169 & 26.18 \\
3 & Buruh tani/Nelayan & 319 & 3.85 \\
& Farm worker/Ship crew & 70 & 0.85 \\
4 & Buruh Pabrik/Factory Employee & 32 & 0.39 \\
5 & PNS/Government Employee & 81 & 0.98 \\
6 & Pegawai Swasta/Private Employee & 136 & 1.64 \\
7 & Wiraswasta/pedagang/ & 57 & 0.69 \\
8 & Entrepreneur/Merchant & 4,309 & 52.02 \\
9 & Tidaknya/Others & $\mathbf{8 , 2 8 4}$ & 100 \\
\hline
\end{tabular}


Bidang usaha yang dikelola KUD Mina Jaya ini menyangkut pelayanan masyarakat di bidang (Efani, 2010):

a. Mengelola unit penyediaan bahan bakar Solar Paket Dealer Nelayan (SPDN) untuk nelayan di TPI Pondok Dadap Sendang Biru.

b. Menyediakan unit penyalur air minum, es balok dan kebutuhan harian nelayan dan unit perumahan yang sangat sederhana.

c. Mengadakan kegiatan tabungan dan peminjaman uang untuk anggota.

SPDN yang terdapat di PPI Pondok Dadap adalah SPDN No. 59.651.01, pengelolaan dilakukan oleh KUD Mina Jaya. Pembelian BBM untuk nelayan di SPDN ini dibatasi 10-15 jurigen (30 liter/jurigen) setiap armada terutama armada kapal sekocianan sedangkan untuk armada payang lebih sedikit karena kebutuhan lama operasi sekitar satu hari dan fishing ground yang lebih dekat. Hal ini dilakukan sebagai antisipasi dari makin terbatasnya pasokan BBM dari Pertamina untuk SPDN di PPI Pondok Dadap. Harga solar yang berlaku di SPDN ini mengikuti harga subsidi dari pemerintah.

Kebutuhan lain yang dikelola oleh KUD Minajaya adalah es balok yang berfungsi untuk mempertahankan kesegearan ikan selama berada di tengah laut sampai didaratkan di Tempat Pelelangan Ikan. Es adalah bahan utama yang dibutuhkan untuk menjaga kualitas ikan yang ditangkap oleh nelayan. Komitmen nelayan di Sendangbiru tidak hanya menghasilkan ikan dengan jumlah yang banyak tetapi juga mempertahankan kulitas ikan agar bernilai jual tinggi. Hal ini seperti dikatakan oleh salah satu pedagang sekaligus pengurus kapal yang bernama Pak Budi berikut ini.

\begin{abstract}
"Nelayan Sendangbiru itu tahu bagaimana caranya supaya ikan itu sampai ke darat dalam kondisi baik. Karena apa? Nelayan Sendangbiru itu nggak mau berangkat kalau nggak ada es. Mereka tau cara memperlakukan ikan supaya tetap segar."
\end{abstract}

Es balok yang digunakan oleh nelayan dibeli dari pabrik es yang dikelola oleh KUD Minajaya. Selain BBM dan es balok, suplai air minum dan kebutuhan lainnya sangat penting bagi kegiatan penangkapan dengan lama perjalanan sampai 1 minggu. KUD Minajaya juga mengelola suplai air untuk kebutuhan nelayan.
KUD Minajaya sebagai satu - satunya koperasi yang berada di Sendangbiru memiliki peran penting dalam kegiatan usaha penduduk setempat. Tidak hanya mengelola kebutuhan nelayan dalam kegiatan usaha penangkapan tetapi juga memberikan skema simpan pinjam bagi anggota. Namun, berdasarkan data tahun 2016 tentang keanggotaan di KUD Minajaya, jumlah anggota koperasi ini hanya 162 orang. Jauh lebih kecil dibandingkan jumlah pengusaha perikanan bahkan jumlah penduduk di Desa Tambakrejo.

\section{Pedagang Logistik Usaha Penangkapan}

Sub sistem penyedia sarana produksi menyangkut kegiatan pengadaan dan penyaluran. Kegiatan ini harus memenuhi beberapa kriteria yaitu tepat waktu, tepat jumlah, tepat jenis, tepat mutu dan tepat produk (Maulidah, 2012). Penyedia sarana produksi perikanan tangkap meliputi penyediaan BBM, air, peralatan dan perlengkapan alat penangkapan dan logistik sesuai kebutuhan dan lama melaut.

Pedagang peralatan dan perlengkapan alat tangkap seperti pancing, senar dan peralatan lainnya dibeli dari pedagang yang berada di sekitar pelabuhan. Termasuk kebutuhan logistik seperti sembako, sayur - mayur dan lauk pauk juga dapat diperoleh dengan mudah karena lokasi penjualan yang sangat dekat dengan titik keberangkatan kapal. Nelayan memiliki kemudahan dalam penyaluran perbekalan karena ada kelompok kuli bongkar yang bertugas untuk mengangkut bahan - bahan dari toko langganan nelayan menuju ke kapal sebelum berangkat. Nelayan membeli bahan - bahan dari pedagang kemudian kuli bongkar yang bertugas untuk mengangkutnya. Sistem pembayaran kuli bongkar diberikan berdasarkan jumlah ikan yang diperoleh oleh nelayan setelah pulang melaut.

\section{Terbentuknya Biaya Transaksi pada Usaha Perikanan Tangkap Sendangbiru}

Biaya transaksi adalah biaya untuk melakukan negosiasi, mengukur, dan memaksakan pertukaran. Selain itu, juga dapat diartikan sebagai biaya pencarian informasi, bisa negosiasi dan keputusan atau eksekusi kontrak, dan biaya pengawasan. Pada kegiatan usaha perikanan tangkap di Sendangbiru hampir seluruh proses usaha dikendalikan oleh pengambek (Manziati et al., 2018). Lebih lanjut dijelaskan bahwa pengambek adalah pemilik modal sekaligus aktor yang memiliki struktur kekuasaan tertinggi 
dalam usaha perikanan tangkap di Sendangbiu. Pengambek bertanggung jawab pada kegiatan usaha nelayan dengan memberikan pinjaman modal serta memenuhi kebutuhan biaya operasional melalui kontrak yang diikat oleh hutang yang tidak pernah lunas.

Teori ekonomi neoklasik selama ini menganggap biaya transaksi dalam kegiatan ekonomi adalah nol. Hal ini disebabkan karena mekanisme pasar dianggap berjalan dengan sempurna tanpa biaya, informasi yang dimiliki pembeli sempurna dan penjual saling berkompetisi untuk menghasilkan harga yang rendah (Stone et al. (1996) dalam Yustika, 2012). Namun pada kenyataannya tidak demikian khususnya dalam kegiatan usaha perikanan tangkap di Sendangbiru. sebagaimana dalam penelitian Manzilati, Efani \& Kornitasari (2018) bahwa struktur kekuasaan tertinggi berada ditangan pengambek yang merupakan pemilik modal, sehingga penentuan harga input produksi yang ditetapkan relatif tinggi. Berdasarkan hasil penelitian, biaya transaksi tidak hanya muncul ketika transaksi terjadi (pasca produksi), tetapi juga sebelum (pra produksi), pada saat produksi dan pasca produksi.

Biaya transaksi pada pasar input kegiatan usaha dimulai ketika sebuah kontrak bisnis antara nelayan dan pengambek telah disepakati. Kontrak bisnis tersebut bersifat informal tanpa adanya hitam diatas putih. Meskipun demikian, kuatnya modal sosial diantara mereka dapat mempertahankan eksistensi kelembagaan tersebut (Manzilati, Efani \& Kornitasari (2018). Sebagaimana dijelaskan oleh Amiruddin (2014) bahwa ketergantungan nelayan pada pemilik modal, merupakan suatu ikatan-ikatan sosial yang menjadi pegangan untuk memperoleh pemenuhan kebutuhan hidupnya. Dalam kesepatan kontrak bisnis tersebut pengambek memberikan pinjaman modal untuk nelayan dengan besaran mulai Rp.50.000.000,- hingga Rp.200.000,sebagaimana penjelasan salah satu informan $A$ dibawah ini.

\section{"Istilahnya pengambek itu kan tanam modal mbak, nelayan dibantu beli kapal. Misalnya punya uang 50 (Juta), mau beli kapal harganya 200 (Juta), itu pengambek sisanya."}

Dengan demikian, terciptanya biaya transaksi pada usaha perikanan tangkap di Pantai Sendangbiru diawali dari kesepakatan kontrak bisnis antara nelayan dan pengambek. Dimana hubungan ini yang biasa disebut sebagai hubungan patron - klien (patronase) telah menjadi bagian dari masyarakat nelayan. Hubungan ini berimplikasi terhadap pertukaran antara dua pihak yang terikat dalam satu kontrak yang tidak tertulis (Sudarmono, Sulehan, Rahamah \& Bakar, 2012). Dalam kontrak tersebut terdapat beberapa hal yang menjadi hak dan kewajiban dari masing -masing pihak. Selain memberikan pinjaman modal, pengambek bertanggungjawab untuk memenuhi kebutuhan input produksi kegiatan penangkapan nelayan dan menjual seluruh hasil tangkapan. Dengan ikatan kontrak tersebut nelayan tidak lagi khawatir dengan kebutuhan operasional usaha karena telah ditanggung oleh pengambek. Kontrak ini tidak bisa dihindarkan karena posisi tawar (bargaining posisition) yang dimiliki oleh nelayan sebagai pemilik usaha sangat kecil dibandingkan pengambek sebagai pemilik modal. Baik secara ekonomi maupun politik nelayan dihadapkan pada kondisi yang tidak kondusif pada struktur pasar di perikanan laut (Qurrata, 2017). Disisi lain kelembagaan ini mampu mendorong keberlanjutan usaha perikanan tangkap karena nelayan merasa terbantu dengan adanya pinjaman modal dan biaya hidup yang jangka waktu dan besaran pengembalian tidak ditentukan karena patron dapat memberikan jaminan pasti pada kebutuhan nelayan (Marijiani, Wahyuni, Satria, Saharuddin \& Kusumastanto, 2014).

Hal tesebut diakui oleh salah satu pengambek bahwa seringkali nelayan meminjam uang untuk kebutuhan hidup ketika terjadi paceklik meskipun hutang sebelumnya belum dilunasi. Jika dilihat dari kacamata sosial, fenomena tersebut seolah menunjukkan kuatnya modal sosial diantara nelayan dan pengambeki. Namun secara bisnis, hal tersebut merupakan upaya pengambek untuk menciptakan ketergantungan dari nelayan. Hal ini sejalan dengan Muhartono \& Nurlaili (2018) bahwa hutang merupakan pengikat antara nelayan dan pengambek. Berikut kutipan wawancara dari salah satu pengambek.

\section{"Ya sekarang gimana ya mbak kalau nggak dipinjami. Nanti urusan uang lima ratus atau berapa malah dia ikut pengambek lain. Kan saya yang susah."}

Hutang yang diberikan oleh pengambek kepada nelayan ketika pertama kali kontrak disepakati merupakan biaya bagi nelayan itu sendiri untuk memulai kegiatan usaha. Meskipun jangka waktu pengembalian tidak ditetapkan tapi 
hutang yang diberikan tetaplah menjadi beban bagi nelayan. Transaksi antara orang per orang yang seolah - olah sebagai tindakan sosial daripada ekonomi seperti ini memiliki hubungan yang tahan lama setelah adanya suatu pertukaran, lebih jauh pelaku ekonomi tersebut tergabung dalam jaringan dari suatu hubungan sosial (Pratama \& Manzilati, 2014). Lebih lanjut menurut Sudarmono, Sulehan, Rahamah \& Bakar, (2012) hubungan tersebut akan menimbulkan dinamika pertukaran yang tidak lagi menyangkut dimensi ekonomi, akan tetapi telah menjadi sebuah ikatan sosial baik yang dapat memberikan keuntungan bagi nelayan sebagai klien maupun pengambek/pemilik modal sebagai klien.

\section{Biaya Transaksi Pasar Input Usaha Perikanan Tangkap di Pantai Sendangbiru}

Pada pembahasan sebelumnya telah dijelaskan mekanisme biaya transaksi pada kegiatan usaha perikanan tangkap di Sendangbiru. Sebagaimana yang telah dijelaskan, biaya operasional nelayan dalam kegiatan ditanggung oleh pengambek_sebagai pemilik modal. Dimana mekanisme yang berjalan merupakan kelembagaan yang telah diakui dan digunakan oleh pelaku usaha perikanan tangkap di Sendangbiru. Kondisi ini menyebabkan harga barang (input produksi) tidak lagi ditentukan oleh mekanisme pasar berdasarkan permintaan dan penawaran. Sebagaimana dalam Mankiw et al. (2012) bahwa permintaan dan penawaran merupakan kekuatan yang menentukan harga dan jumlah barang di pasar. Namun hal ini tidak terjadi pada pasar input produksi usaha perikanan tangkap di Sendangbiru.

Berdasarkan hasil penelitian ini, diketahui bahwa tidak hanya pengambek yang mengeluarkan biaya untuk dapat berinvestasi pada kegiatan usaha nelayan. Sejalan dengan pembahasan sebelumnya, dalam kegiatan usaha ini terdapat dua hal yang menjadi beban bagi nelayan. Pertama, kebutuhan perbekalan yang telah disediakan oleh pengambek memiliki harga yang lebih tinggi dibandingkan dengan harga barang di pasaran. Kedua, biaya pengiriman perbekalan dari toko oleh kuli bongkar ditanggung nelayan. Sehingga pendekatan ekonomi klasik tentang penentuan harga berdasarkan permintaan dan penawaran tidak berlaku dalam kasus ini. Lebih lanjut menurut Hariyati (2007), dalam implementasi sehari-hari bisa saja harga yang terbentuk di pasar tidak selalu berjalan sesuai dengan mekanisme pasar yang wajar, misalnya tidak ada unsur intervensi, tidak ada unsur permainan oleh sekelompok kekuatan tertentu yang membentuk kartel dan sebagainya. Namun pada usaha perikanan tangkap, penentuan harga input produksi ditentukan oleh pengambek sebagai konsekuensi dari kemudahan akses dan pembayaran yang tidak mengikat bagi nelayan.

Perbekalan dalam kegiatan penangkapan seperti bahan bakar minyak, air, es, bahan makanan dan barang konsumsi lainnya akan dikirim oleh pengambek ketika nelayan memberi tahu kan berangkat melaut. Nelayan cukup menelepon untuk memberi tahu, kemudian pengambek akan penyiapkan perbekalannya. Namun biaya tersebut tetap akan ditagihkan kepada nelayan melalui pemotongan hasil penjualan ikan. Berikut adalah kutipan wawancara dari salah satu informan dalam peneltian ini.

"Ini semua (perbekalan melaut) dari pengurus (pengambek) mbak. Jadi kalau mau berangkat ngebel, mau berangkat jam segini, perlu ini ini ini. Nanti pengurus yang nyiapkan semuanya. Kita tinggal nunggu aja."

Kemudahan tersebut tentu saja sangat membantu nelayan dalam melakukan kegiatan usahanya. Mereka tidak terlalu memusingkan biaya operasional untuk berangkat melaut. Namun dengan kemudahan itu nelayan harus mau menerima harga beli yang lebih tinggi dari harga pasaran. Diakui oleh nelayan bahwa perbekalan dari pengambek harganya akan lebih tinggi dari harga toko. Hal ini sejalan dengan penjelasan Nelayan B sebagai berikut.

"Tapi kalau dapat dari pengambek harganya beda. Misal rokok harganya ditoko sepuluh ribu, dari pengambek bisa duabelas, tiga belas. Yang lain - lain juga sama gitu."

Dari kutipan wawancara diatas dapat diketahui besaran persentase harga jual barang dari pengambek ke nelayan sekitar 20\% - 30\% dari harga pasaran di toko. Biaya tersebut nantinya akan dipotong dari hasil penjualan ikan dari nelayan. Artinya, ada harga yang harus dibayar oleh nelayan untuk mendapatkan kemudahan akses dalam pemenuhan kebutuhan operasional usaha. Meskipun nelayan bisa mendapatkan harga perbekalan yang lebih rendah dari pengambek, namun nelayan tidak punya pilihan lain selain menerima harga dari pengambek asalkan bisa pergi melaut dan mendapatkan ikan. 
Bentuk biaya transaksi kedua di pasar input usaha perikanan tangkap Sendangbiru yang menjadi beban nelayan adalah biaya jasa pengiriman. Perbekalan melaut yang dikirim oleh pengambek dikirimkan melalui kuli bongkar. Untuk membayar jasa pengiriman tersebut nelayan membayar dengan ikan yang didapat setelah melaut sekitar $5 \mathrm{~kg}$ ikan.

Berdasarkan hasil penelitian dan pembahasan diatas, dapat disimpulkan bahwa biaya transaksi di pasar input usaha perikanan tangkap khususnya bagi nelayan terdiri dari 3 bentuk. Pertama, biaya komunikasi yang dikeluarkan oleh nelayan untuk memberitahu pengambek bahwa mereka akan pergi melaut. Selain itu juga berfungsi untuk melakukan komunikasi dalam kegiatan usaha. Besaran biaya ini tergantung dari intensitas nelayan menghubungi pengambek, rata - rata sekitar Rp.50.000,- per bulan.

Kedua, selisih harga pada pembelian perbekalan dan peralatan yang digunakan untuk melaut. Sebagimana yang telah dijelaskan sebelumnya, untuk mendapatkan sarana produksi dengan cepat dan mudah nelayan harus menerima harga yang lebih tinggi dari pengambek sebagai penyedia input produksi. Besaran selisih yang diterima nelayan dibandingkan ketika nelayan membeli barang - barang sendiri sekitar 20\%-30\%.

Ketiga, biaya jasa pengiriman perbekalan dari toko ke kapal. Harga yang lebih mahal, pengambek tidak mengirimkan perbekalan secara gratis. Berdasarkan hasil peneltian diketahui bahwa pengambek tidak berhubungan dengan kuli bongkar yang membawa perbekalan nelayan. Pengambek hanya menghubungi pihak toko, selanjutnya kuli bongkar yang mengantar ke kapal nelayan dengan biaya jasa yang harus ditanggung oleh nelayan.

\section{KESIMPULAN DAN REKOMENDASI KEBIJAKAN}

\section{Kesimpulan}

Berdasarkan hasil penelitian dapat disimpulkan bahwa harga barang tidak selalu dipengaruhi oleh mekanisme pasar berdasarkan hubungan permintaan dan penawaran sebagaimana konsep ekonomi neoklasik. Lebih lanjut dalam kegiatan usaha perikanan tangkap di Sendangbiru biaya produksi tidak hanya dikeluarkan untuk kebutuhan modal sarana dan prasarana seperti kapal dan alat penangkapan, kebutuhan perbekalan dan tenaga kerja. Pada praktiknya, terdapat biaya transaksi yang harus mereka keluarkan tidak hanya ketika pasca produksi. Mekanisme biaya transaksi pada usaha perikanan tangkap di Pantai Sendangbiru muncul ketika kelembagaan kontrak bisnis non formal antara nelayan dan pengambek disepakati dan mulai berjalan. Kontrak tersebut yang mengatur hampir seluruh proses kegiatan usaha penangkapan. Selanjutnya, biaya transaksi di pasar input usaha perikanan tangkap di Pantai Sendangbiru terdiri dari biaya komunikasi, selisih harga pada barang - barang input produksi yang disediakan oleh pengambek, dan biaya jasa pengiriman perbekalan oleh kuli bongkar ke kapal nelayan.

\section{Rekomendasi Kebijakan}

Dengan demikian, dalam membuat program ataupun kebijakan pembiayaan perikanan pemerintah dapat mempertimbangkan keberadaan nelayan kecil yang berada pada posisi marginal. Selama ini program yang diberikan ternyata hanya dapat dijangkau oleh pengusaha menengah sehingga nelayan kecil tidak tahu sama sekali. Akibatnya, nelayan kecil sangat bergantung pada pengambek/juragan dalam menjaga keberlangsungan usahanya. Selain itu perlu adanya pemberdayaan kelompok nelayan untuk meningkatkan kapasitas sumberdaya manusia yang mampu melakukan manajemen usaha dengan baik. Optimalisasi peran koperasi perikanan juga perlu dilakukan sebagai penyedia input produksi untuk mengurangi dominasi pengambek dalam kegiatan operasional sehingga dapat meningkatkan pendapatan nelayan.

\section{UCAPAN TERIMA KASIH}

Penulis menyampaikan terima kasih kepada seluruh pihak yang telah membantu pelaksanaan penelitianini. Terimakasih kepada pelaku usaha perikanan tangkap dan UPT P2SKP Pondokdadap Sendangbiru yang telah bersedia menjadi informan. Terimakasih juga disampaikan kepada tim yang telah membantu teknis kegiatan sehingga penelitian ini dapat terselesaikan dengan baik.

\section{DAFTAR PUSTAKA}

Alhuda, S. Z, Anna. \& I, Rustikawati. (2016). Analisis Produktivitas dan Kinerja Nelayan Purse Sein di Pelabuhan Perikanan Pantai Lempasing, Bandar Lampung. Jurnal Perikanan Kelautan, Vol. 7(1), 
30 - 40. Retrieved from http://jurnal.unpad.ac.id/ jpk/article/view/ 13933/6671.

Amiruddin, S. (2014) Jaringan Sosial Pemasaran pada Komunitas Nelayan Tradisional Banten. Jurnal Komunitas: Research \& Learning in Sociology and Anthropology, Vol. 6(1), 106 - 115. DOI:http://dx.doi.org/10.15294/komunitas. v6i1.2949.

Black, J.A. \& Champion, D.J. (2001). Metode dan Masalah: Penelitian Sosial. Bandung, ID: PT. Refika Aditama.

Cahyono, B.D. \& Nadjib, M. (2014). Implikasi Kendala Struktural dan Kelangkaan Modal Terhadap Perilaku Sosial Ekonomi Nelayan. Jurnal Ekonomi dan Pembangunan, Vol 22(2), 119 - 133. DOI: http://dx.doi.org/10.14203/ JEP.22.2.2014.119-133.

Efani, A. (2010). Fungsi Produksi Stochastic Frontier dn Efisiensi Teknis Usaha Penangkapan Tuna. Disertasi. PPS Fakultas Perikanan UB: Malang.

Halim, D. (2013). Faktor - Faktor yang Mempengaruhi Pendapatan Masyarakat Nelayan Pantai di Kabupaten Bantul Tahun 2012. Modus Journals, Vol. 25(2), 171 - 187. https://doi.org/10.24002/ modus.v25i2.561.

Hariyati, Y. (2007). Ekonomi Mikro(Pendekatan Matematis dan Grafis). Jember, ID: CSS Universitas Jember.

Ismadi. (2010). Studi Dampak Nelayan Andon Dan Perubahan Sosial Pada Masyarakat Nelayan Desa Tambakrejo, Kecamatan Sumber Manjing Wetan, Kab.Malang. Disertasi. Fakultas Pertanian Universitas Brawijaya.

Jaya, M.M., Wiryawan, B., \& Simbolon, D. (2017). Keberlanjutan Perikanan Tuna di Perairan Sendangbiru Kabupaten Malang. Albacore, Vol. 1(1), 111-125. Retrieved from http://jesl. journal.ipb.ac.id/index.php/pspalbacore/article/ view/16244.

Marijiani, E.S. Wahyuni, A. Satria, Saharuddin, T, Kusumastanto. (2014). Transformasi Pranata Patronase Masyarakat Nelayan: dari Ekonomi Moralitas Menuju Ekonomi Pasar. Jurnal Komunitasl, Vol. 6(1), 115 - 134. DOI: 10.15294/ komunitas.v6i1.2950.

Maulidah, S. (2012). Pengantar Manajemen Agribisnis. Malang, ID: UB Press.

Mankiw, N.G., E. Quah \& P. Wilson. (2012). Pengantar Ekonomi Mikro. Jakarta, ID: Penerbit Salemba Empat.

Manzilati, A., Efani, A., \& Kornitasari, Y. (2018). Identifikasi Pembiayaan Sektor Perikanan Melalui Hubungan Principal Agent pada Kontrak Bagi Hasil: Skenario Praktis dan Aplikasi (Studi Kasus Perikanan Pesisir Malang Selatan). Laporan Penelitian Terapan Unggulan Perguruan Tunggi Tahun Terakhir. Universitas Brawijaya.
Miles, B. \& Huberman, M. (2014). Qualitative data analysis: a methods sourcebook / Matthew B. Miles, A. Michael Huberman, Johnny Saldaña, Arizona State University; Third edition. London, UK: Sage Publication.

Moleong, L. (2006). Metodologi Penelitian Kualitatif. Bandung, ID: PT. Remaja Rosdakarya.

Muhartono, R. \& Nuralaili. (2018). Hutang sebagai Pengikat Hubungan Nelayan dan Pengambe' di Kabupaten Jember, Provinsi Jawa Timur. Jurnal Sosial Ekonomi Kelautan dan Perikanan, Vol. 13(2), 239 - 248. http://dx.doi.org/10.15578/ jsekp.v13i2.6869.

P2SKP Pondokdadap. (2017). Laporan Mnitoring PPP Pondokdadap 2017. P2SKP Pondokdadap: Malang.

Pratama, Y.P., \& Manzilati, A. (2014). Suara Akar Rumput: Kebudayaan yang Mendasari Perilaku Ekonomi. Jurnal IImu Ekonomi dan Pembangunan (JIEP), Vol. 14(1). DOI: https://jurnal.uns.ac.id/jiep/ article/view/2110.

Qurrata, V.A. (2017). Patron Client: Kontrak Semi Mudharabah dalam Teori Keagenan di Perikanan Laut. El Dinar Jurnal Keuangan dan Perbankan Syariah, Vol. 5(1), 1 - 8. DOI: http://dx.doi. org/10.18860/ed.v5i1.5230.

Siswoyo, H., Setyono, D.J., \& Fuah, A.M. (2013). Analisis Kelembagaan Dan Peranannya Terhadap Pendapatan Peternak Di Kelompok Tani Simpay Tampomas Kabupaten Sumedang Provinsi Jawa Barat (Studi Kasus Di Kelompok Peternak Kambing Simpay Tampomas Kecamatan Cimalaka Sumedang). Jurnal IImu Produksi dan Teknologi Hasil Peternakan, Vol. 1(3), 172 - 178. DOI: https://doi.org/10.29244/jipthp.

Sudarmono, Sulehan, J., Rahamah, N., \& Bakar, A. (2012). Dinamik langganan dalam masyarakat nelayan: Artikulasi ragam pengeluaran perikanan berskala kecil di Kelurahan Cambayya, Kota Makassar, Sulawesi Selatan, Indonesia. Malaysia Journal of Society and Space, Vol. 8(8), 65 - 75. Retrieved from http://journalarticle.ukm. my/5732/1/7c.geografia-nov\% 25202012-sudarmono-edam1.pdf.

Sugiyono. (2014). Metode Penelitian Kuantitatif, Kualitatif, dan R\&D. Bandung, ID: Penerbit Alfabeta.

Suharto, R.B. (2012). Keuntungan Maksimum Usaha Nelayan di Kecamatan Balikpapan Timur. Forum Ekonomi, Vol. 15(2), 37 - 46.

Yustika, A.E. (2012). Ekonomi Kelembagaan; Definisi, Teori dan Strategi. Jakarta, ID: Penerbit Erlangga.

Zakaria, W.A. (2009). Penguatan kelembagaan kelompok tani kunci kesejahteraan petani. Jurnal Agro Ekonomi, Vol. 1(1), 294 - 315. Retrived from https://pse.litbang.pertanian.go.id/ind/pdffiles/ MP_Pros_C3_2009.pdf. 